\title{
A raposa e a passarinha
}

Rodrigo Fernandes de SOUSA* Viviane Moraes de Caldas GOMES ${ }^{* *}$

Enquanto Renart se lamenta, ele percebe uma passarinha empoleirada sobre um carvalho: a árvore tinha um lugar onde ela havia colocado seus ovos.

"Bom dia, querida amiga, desça daí e venha me dar um beijo."

- De jeito nenhum, Renart. Não se pode ser amigo de um bandido da sua laia. Você fez tantas maldades a tantos pássaros e a tantos bichos que não sabemos mais o que pensar sobre você. Em que você vai se transformar? O mal o corrompeu tanto que é impossível confiar em você.

- Mulher, também é verdade que seu filho é meu afilhado por meio do santo batismo e eu não penso em lhe fazer mal, juro a você. E sabe por quê? É natural que eu lhe diga. O nosso Nobre Senhor Leão nos fez jurar a paz, e por muito tempo, como agrada a Deus. Em todo o seu reino, ele fez seus vassalos prometerem respeitar esse juramento de paz e assegurar sua manutenção. Eis que isto alegrou o coração dos pequenos. Estão terminadas as disputas, os processos, as guerras mortais a torto e a direito, e os bichos, grandes e pequenos, deverão viver tranquilos!

- Você está querendo me enganar, Renart. Vá procurar outro, eu lhe peço. Você não vai me convencer a beijá-lo.

A raposa, percebendo que a sua comadre não acreditava nela, acrescentou:

- Escute, mulher, já que você tem medo de mim, eu manterei meus olhos bem fechados ao beijá-la.

- Nestas condições, eu aceito.

A passarinha, que não queria se arriscar ao beijar a raposa, pega um musgo e algumas folhas com os quais faz cócegas no focinho da raposa. E a raposa, crendo tê-la enganado, apenas abocanha a folhagem que fica presa em seu bigode.

\footnotetext{
* Aluno do Programa de Pós-Graduação em Linguagem e Ensino (Pós-LE) da Unidade Acadêmica de Letras (UAL) da Universidade Federal de Campina Grande (UFCG). E-mail: rfernandesufcg@ gmail.com.

** Aluna do Programa de Pós-Graduação em Linguagem e Ensino (Pós-LE) da Unidade Acadêmica de Letras (UAL) da Universidade Federal de Campina Grande (UFCG). E-mail: vivianegomes@ gmx.de.
} 
-Ah Renart!, grita ela, de que acordo você falava mesmo? Você teria quebrado o acordo de paz se eu não tivesse me afastado a tempo. Você alegava que a paz havia sido decretada e jurada. Seu rei não se cercou de garantias suficientes.

Mas a raposa, às gargalhadas, disse:

- Era só uma brincadeira para fazer você sentir medo. Pouco importa. Vamos recomeçar, vou fechar os olhos de novo.

- Permaneça imóvel, disse a passarinha.

$\mathrm{O}$ enganador se prepara e a passarinha vai até ele e apenas roça-lhe o focinho, mas sem tocá-lo. Novamente uma mordida da raposa, na esperança de agarrá-la! Sem chance.

- Nunca mais vou acreditar em você, raposa. Como agir diferente! Que o diabo me carregue se eu confiar em você de novo.

- Você é muito medrosa! Eu queria assustá-la e colocá-la a prova. Eu lhe juro que eu não tinha nenhuma intenção maldosa com isso. Venha de novo, mais uma vez. Não há dois sem três. Em nome da virtude da bondade, da caridade, da constância, de pé querida amiga! Pela fé que você me deve e que você deve ao meu afilhado que canta lá em cima sobre sua tília, selemos nosso acordo. Misericórdia a todos os pecadores!

Mas a passarinha, que não era louca nem boba, faz-se de surda e não se mexe do galho onde estava empoleirada. Assim que a raposa começa a tagarelar, eis que os caçadores com seus cães e cornetas põem-se no seu encalço. A raposa, então, foge depressa, o rabo armado como um arco em meio aos gritos emitidos pelos homens e a algazarra das cornetas e das trompas. A raposa foge desesperadamente enquanto a passarinha grita: "A paz de que você falava já terminou, Renart? Para onde você vai? Volte aqui."

A raposa, ainda correndo, grita uma mentira para a passarinha:

- Mulher, nós juramos respeitar a trégua e até mesmo permanecermos em paz. Mas nem todo mundo jurou. São os cães jovens que se aproximam; eles não estão engajados em respeitar a paz que seus pais juraram. No dia em que seus pais e avós prometeram manter a paz, eles eram muito pequenos para participar da cerimônia.

- Como você é desconfiado! Você acredita que eles vão infringir a paz? Volte aqui e venha me dar um beijo!

- O momento não me parece propício.

- Mas já que o seu rei fez jurar a paz! 
Sem responder, Renart foge pelos atalhos que ele bem conhecia, mas só para cair sobre um monge que trazia na coleira, ao longo do caminho, dois grandes cães de guarda. Um camponês que estava em frente aos caçadores grita para o religioso soltar os cães. "É para a raposa: ela não irá muito longe.” Palavras que arrancaram um suspiro de Renart, pois ele sabia muito bem que passaria um terrível quarto de hora se fosse pego. Ela se viu cercada por pessoas prontas a agarrá-la e a esfolá-la com seus machados. Ela temia perder por ali os pêlos e a pele se, apesar de tão boa falante que era, não pudesse fazer prevalecer a astúcia sobre a força. Não havia meios de fugir e a raposa, presa, não podia nem se esconder nem fugir: para onde ela poderia ir, perguntam-se a ela. E o monge, que a viu, se aproxima ameaçador:

- Ha! Ha! Raça suja! Você não vai se salvar.

- Em nome de Deus, meu pai, não fale assim. Um eremita, um homem santo como o senhor deve evitar prejudicar qualquer pessoa. Se o senhor ou os seus cães se colocarem no meu caminho, é o senhor que será responsabilizado. Mas serei eu que estarei perdido - e furioso de o estar -, pois esses cães e eu efetuamos uma corrida numa disputa de repercussões consideráveis.

Considerando que Renart está sendo verdadeiro, o monge o recomenda a Deus e a São Julião antes de dar meia volta. Imediatamente, a raposa toca seu cavalo com a espora e retoma a fuga por um caminho que desemboca num vale através dos campos. Os gritos que crescem atrás dele lhe fazem apertar o passo. Além disso, ele salta um largo fosso ao longo do caminho, fazendo com que os cães percam seu rastro, o que os leva a abandonar a disputa. Uma vez perdidos seus caçadores, Renart nem se pergunta pelo restante, ele teme também os dentes dos cães de guarda. Claro, ele está cansado pelo longo percurso que teve de percorrer o dia todo, por causa do azar que se abateu sobre ele. Mas o que importa! Ei-lo em segurança. Ele não pára! Que provação foi aquela! E se derrama em ameaças contra aqueles que o atacaram. 